\title{
DESAIN PEMBELAJARAN MENGGUNAKAN KONTEKS PERKEMBANGBIAKAN HEWAN SECARA VEGETATIF PADA MATERI BENTUK PANGKAT DI SEKOLAH MENENGAH PERTAMA
}

\author{
Pramanika Arieyantini $^{1}$, Ratu Ilma Indra Putri ${ }^{2}$, Nila Kesumawati ${ }^{3}$ \\ ${ }^{1,2}$ Program Studi Pendidikan Matematika FKIP Universitas Sriwijaya \\ ${ }^{3}$ Program Studi Pendidikan Matematika FKIP U.PGRI Palembang \\ pramanika.pcmtk2011@yahoo.com
}

\begin{abstract}
Abstrak
Penelitian ini bertujuan menghasilkan lintasan belajar yang dapat membantu siswa memahami konsep bentuk pangkat melalui konteks perkembangbiakan hewan secara vegetatif. Design Research dipilih sebagai cara yang tepat untuk mencapai tujuan. Lintasan belajar (Hypotetical Learning Trajectory) dalam design research memegang peranan penting sebagai desain dan instrumen penelitian. Lintasan belajar dirancang dalam tahap desain awal dan diujikan pada 50 siswa kelas IX (yaitu, 6 siswa pada pilot experiment dan 44 siswa pada teaching experiment) SMP YPI Tunas Bangsa Palembang. Hasil dari percobaan pembelajaran menunjukkan bahwa aktivitas menggambar proses perkembangbiakan hewan secara vegetatif dapat mendorong siswa untuk melihat bentuk penggandaan yang terjadi, dan ketika siswa melihat penggandaan melalui pemodelan (bagan/skema) yang siswa buat, siswa memiliki ide untuk menghitung hewan baru yang terbentuk kemudian menggunakan bilangan kelipatan untuk menentukan banyak hewan baru. Dari bilangan kelipatan, ide untuk menyatakannya kedalam bentuk perkalian berulang membawa siswa ke dalam definisi bentuk pangkat. Berdasarkan hasil tersebut, disarankan untuk menggunakan konteks yang mengandung bentuk penggandaan, membiarkan siswa untuk melihat penggandaan, dan membiarkan siswa untuk mematematikakannya menjadi konsep yang mendasar ketika siswa sedang belajar bentuk pangkat.
\end{abstract}

Kata Kunci: Design Research, Lintasan Belajar, Bentuk Pangkat, Perkembangbiakan Hewan secara Vegetatif.

\begin{abstract}
The research is purposed to generate a learning trajectory that supports students to understand the concepts of exponential through the context vegetative propagation in animals. The Design Research was chosen as the exact method to achive the objective. Hypotetical learning trajectory in the design research played an important role as the design and research instrument. Hypotetical learning trajectory was designed as the preliminary design and was examined to 50 students from the ninth graders of YPI Tunas Bangsa Junior high school. (e.g 6 students from pilot experiment and 44 students from teaching experiment). The result of the learning experiment showed that drawing activity of the process of animal vegetative propagation could motivate the students to see the form of the animal multiplication. While seeing the animal multiplication through modeling (scheme, chart, and diagram), the students had an idea to calculate new animals had been formed, and used multiple numeral to determine the sum of the new animals. From the multiple numeral, an idea to state it in terms of repetitive numeral would bring the students into a definition of exponential. Based on the result above, it's suggested that context containing multiplication form be used, let the students see multiplication, and the students do it mathematically into the basic concept when they are learning exponential.
\end{abstract}

Keywords: Design Research, Hypothetical Learning Trajectory, Exponential, Vegetative Propagation in Animals. 


\section{PENDAHULUAN}

Ketika bilangan-bilangan dalam dunia teknologi menjadi sangat kecil atau sangat besar, maka menyajikannya dalam bentuk yang standar tidaklah praktis. Notasi pangkat jauh lebih efisien untuk menyampaikan informasi numerik atau kuantitatif. Inilah salah satu manfaat bentuk pangkat, yaitu dapat menuliskan suatu bilangan yang sangat besar atau sangat kecil dengan praktis (Kanginan, 2004).

Notasi pangkat (eksponensial) termasuk dalam kelas aljabar dan merupakan salah satu materi penting dalam matematika untuk dipelajari (Engel dalam de Lange, 1987:23-24). Namun kenyataannya, anak-anak menjadi bingung untuk mengingat aturan pangkat. Hasil penelitian Agustin \& Linguistika (2012) menunjukkan bahwa bilangan berpangkat tergolong materi yang sulit karena telah teridentifikasi banyak siswa yang melakukan kesalahan dalam menyelesaikan soal yang diberikan.

Sejalan dengan itu, hasil penelitian yang dilakukan Mahmuda (2011) menunjukkan bahwa kesalahan yang dilakukan siswa dalam menyelesaikan soal bentuk pangkat terdiri dari kesalahan konseptual (kesalahan dalam memahami sifat atau aturan bentuk pangkat) dan kesalahan prosedural (kesalahan dalam menentukan nilai dari suatu bilangan berpangkat, mengubah suatu bilangan dalam bentuk pangkat, kesalahan dalam perhitungan, kesalahan dalam memahami dan mencermati soal).

Keadaan tersebut juga diperkuat lagi oleh hasil penelitian Rudiati (2012) mengatakan bahwa kenyataan yang ada siswa hanya menghafal konsep/rumus dan kurang mampu menggunakan konsep tersebut jika menemui masalah dalam kehidupan nyata.

Freudenthal (1991) mengusulkan perlunya menghubungkan matematika dengan realitas situasi sehari-hari siswa. Oleh karena itu, pada penelitian ini digunakan konteks sebagai suatu perkenalan ataupun situasi awal dalam pembelajaran.

Van de Walle (2008) mengatakan bahwa konsep eksponensial terlihat dalam kontekskonteks nyata untuk meninjau ulang arti dari pangkat. Contohnya pertumbuhan organisme bersel satu. Bilangan dasar dari eksponen dinamakan faktor pertumbuhan.

Pada penelitian ini, konteks yang digunakan sebagai suatu perkenalan ataupun situasi awal dalam pembelajaran adalah perkembangbiakan hewan secara vegetatif yang diarahkan kepada konsep pertumbuhan organisme.

Perkembangbiakan secara vegetatif adalah terjadinya individu baru tanpa adanya peleburan sel kelamin jantan dan sel kelamin betina. Oleh karena itu individu baru hasil keturunan perkembangbiakan vegetatif mempunyai sifat identik dengan induknya. Adapun beberapa hewan yang berkembangbiak secara vegetatif adalah Amoeba dan Planaria. Amoeba 
merupakan hewan bersel satu yang berkembangbiak dengan cara membelah diri disebut dengan pembelahan biner. Setiap satu sel akan membelah menjadi dua sel yang identik (sama satu sama lain). Dua sel ini akan membelah menjadi empat dan begitu seterusnya. Sedangkan, Planaria merupakan hewan yang berkembangbiak dengan cara fragmentasi. Fragmentasi adalah cara perkembangbiakan dengan pemisahan (pemutusan) diri, tubuh yang putus dapat tumbuh menjadi individu baru (Kuswanti et al, 2008:83-85).

Melalui situasi perkembangbiakan hewan secara vegetatif inilah diharapkan siswa akan lebih memahami konsep bentuk pangkat karena suatu pengetahuan akan menjadi bermakna bagi siswa jika proses pembelajaran dilaksanakan dalam suatu konteks (CORD dalam Wijaya, 2012:20). Sehingga ketika mereka menemukan kesulitan sebaiknya mereka menulis ekspresi yang ekuivalen tanpa pangkat.

Berdasarkan uraian di atas yang menjadi rumusan masalah penelitian ini adalah "Bagaimana menghasilkan lintasan belajar yang dapat membantu siswa memahami konsep bentuk pangkat melalui konteks perkembangbiakan hewan secara vegetatif?"

Hasil dari penelitian ini diharapkan dapat dijadikan sebagai bahan tambahan informasi dalam inovasi pembelajaran, dan meningkatkan profesionalisme guru dalam strategi pengajaran bagi pembelajaran matematika terutama materi bentuk pangkat. Serta dapat memberikan suasana baru bagi siswa, memotivasi siswa, dan memperkaya pengalaman belajar siswa dalam upaya meningkatkan prestasi belajar matematika.

\section{METODE}

Penelitian ini melibatkan 50 siswa (yaitu 6 siswa dalam pilot experiment dan 44 siswa dalam teaching experiment) dan seorang guru kelas IX di Sekolah Menengah Pertama (SMP) YPI Tunas Bangsa Palembang. Metode penelitian yang digunakan adalah design research. Design research merupakan suatu kajian sistematis tentang merancang, mengembangkan dan mengevaluasi intervensi pendidikan (seperti program, strategi dan bahan pembelajaran, produk dan sistem) sebagai solusi untuk memecahkan masalah yang kompleks dalam praktik pendidikan, yang juga bertujuan untuk memajukan pengetahuan kita tentang karakteristik dari intervensi-intervensi tersebut serta proses perancangan dan pengembangannya (Plomp \& Nieveen, 2007).

Data dalam penelitian ini dikumpulkan dengan cara Wawancara dengan pembimbing dan guru model, Video dan foto, Observasi, Catatan lapangan, serta Tes tertulis.

Penelitian ini terdiri dari tiga tahapan design research (Gravemeijer \& Cobb, 2006), yaitu: 


\section{Preparing for Experiment (Persiapan untuk Penelitian) dan Preliminary Design (Desain Pendahuluan)}
a. Kajian Literatur
b. Meneliti Kemampuan Awal Siswa
c. Mendesain Dugaan Lintasan Belajar (Hypothetical Learning Trajectory)

\section{Pilot dan Teaching Experiment}

\section{a. Preliminary Teaching Experiment (Pilot Experiment)}

Pada tahap ini bertujuan untuk mengujicobakan HLT yang telah didesain dengan tujuan untuk mengetahui sejauh mana konjektur dan instrumen yang telah dibuat peneliti dapat terlaksana. Uji coba penelitian ini dilakukan untuk beberapa orang siswa kelas non subjek. Hasil uji coba kelas non subjek akan digunakan untuk merevisi aktivitas dan konjektur siswa sebelum dilakukan penelitian sesungguhnya (Teaching Experiment).

\section{b. Teaching Experiment}

Tahap teaching experiment merupakan tahap inti dari sebuah desain riset. Pada tahap ini HLT yang telah didesain dan diperbaiki pada tahap sebelumnya diujicobakan di kelas sesungguhnya yang menjadi subjek penelitian. Guru bertindak sebagai pengajar sedangkan peneliti mengobservasi dan menganalisa setiap aktivitas belajar siswa selama proses belajar berlangsung.

\section{Retrospective Analysis}

Data yang diperoleh dari seluruh aktivitas pembelajaran di kelas selama pilot experiment dan teaching experiment akan dianalisis. Kemudian, HLT yang telah didesain dibandingkan dengan proses pembelajaran yang berlangsung untuk menjawab rumusan masalah penelitian. Tujuan dari retrospective analysis secara umum adalah untuk mengembangkan local instructional theory. Oleh karena itu, feedback dari guru sangatlah bermanfaat guna memberikan informasi kepada peneliti mengenai perbedaan cara mengajar yang secara teori dapat disesuaikan pada berbagai macam keadaan di kelas. Dengan demikian akan diperoleh desain pembelajaran yang lebih baik lagi.

\section{HASIL DAN PEMBAHASAN}

\section{Hasil}

Hasil dari penelitian ini adalah lintasan belajar yang dapat membantu siswa memahami konsep bentuk pangkat melalui konteks perkembangbiakan hewan secara vegetatif. Pada tahap pelaksanaannya penelitian ini tidak terlepas dari Hypothetical Learning Trajectory 
(HLT) yang telah disesuaikan dengan rencana materi pembelajaran. HLT merupakan peta konsep yang akan dilalui siswa selama proses pembelajaran.

Pendesainan aktivitas untuk pembelajaran materi bentuk pangkat terdiri dari tiga aktivitas yang telah didesain berdasarkan HLT dan perkiraan hasil proses berpikir siswa yang telah dihipotesakan melalui konteks perkembangbiakan hewan secara vegetatif.

Adapun penjabaran aktivitas yang telah dilalui siswa antara lain:

\section{Tes Awal}

Ada tiga permasalahan yang diberikan pada tes awal ini. Permasalahan pertama dan kedua bertujuan memeriksa kemampuan siswa dalam membentuk perkalian dari suatu objek. Mulanya siswa diminta menggambar susunan kue yang disediakan di Lembar Aktivitas Siswa (LAS), menghitung banyaknya kemudian membentuknya menjadi perkalian. Sebanyak $75 \%$ siswa mampu menjawab dengan baik permasalahan ini. Berikut merupakan jawaban siswa terhadap permasalahan yang diberikan.

\section{Permasalahan 1:}

a. Buatlah gambaran dari kue yang ada di atas pada box yang tersedia!

b. Berapa jumlah kue yang disusun Karin pada gambar di atas? Bagaimana cara kalian menghitungnya?

Jawaban:

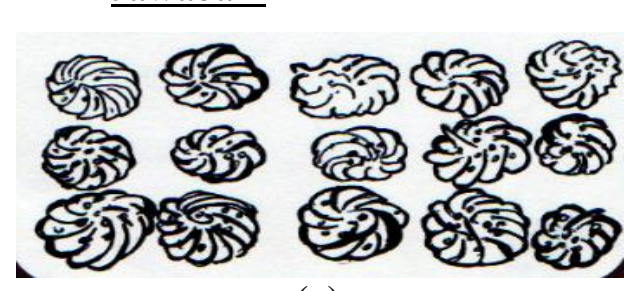

(a)

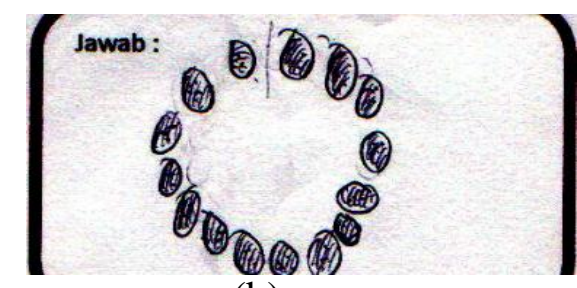

(b)

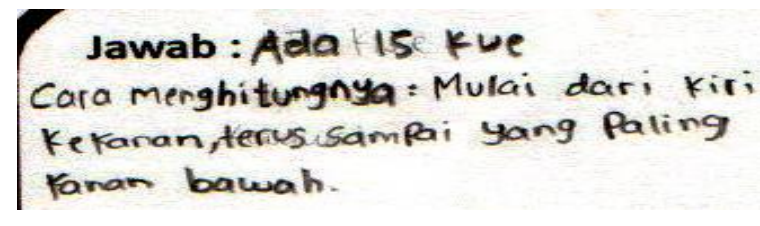

(c)

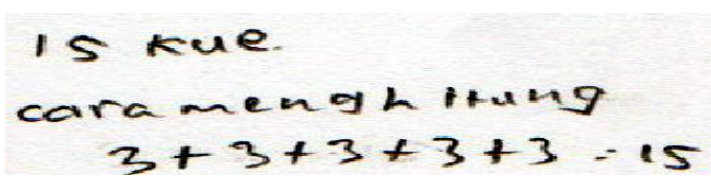

(d)

Gambar 1. Gambar Susunan Kue dan Strategi Siswa Menghitung Banyaknya Kue

\section{Permasalahan 2:}

Tuliskan jumlah kue yang disusun Karin dalam bentuk perkalian! Dapatkah dibentuk perpangkatan? Mengapa?

Jawaban: 
Jawab: Jumlah kue : $3 \times 5=15$

Tidak dapat.

Karena angkanya gangil judi hidak bisa dipangeatkan.

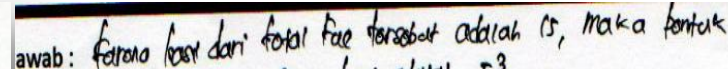
perpangeatan yarg paring tepat adaliah $5^{3}$

$3 \times 5=15$

$=5^{3}$

(a)

(b)

Gambar 2. Kekeliruan Siswa dalam Konsep Perpangkatan

Sedangkan permasalahan ketiga bertujuan melihat kemampuan siswa dalam mengelompokkan angka kemudian membuat bentuk pangkat berdasarkan angka yang sama. Akan tetapi tidak ada satu siswapun yang dapat menjawab permasalahan ini dengan baik.

Permasalahan 3:

Ubahlah bentuk perkalian berikut ke dalam bentuk perpangkatan!

a. $2 \times 2 \times 3 \times 3$

b. $2 \times 8$

c. $4 \times 25$

d. $15 \times 27$

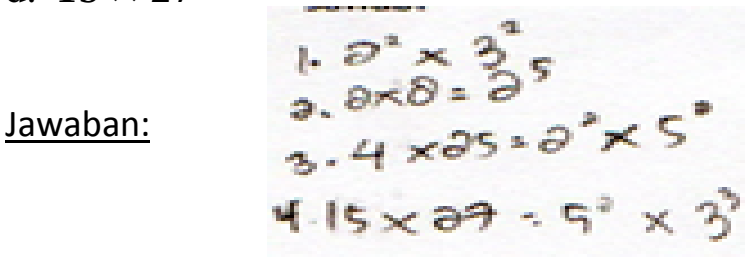

(a)

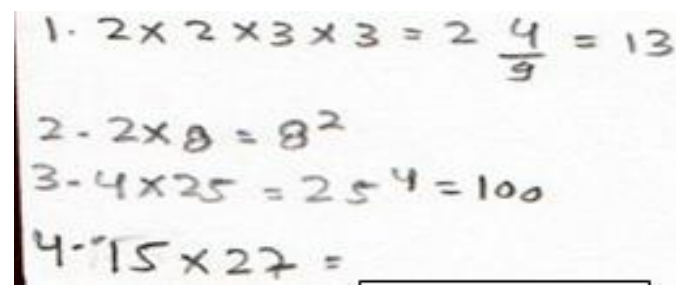

(b)

Gambar 3. Jawaban Siswa tentang Pengelompokkan Angka

2. Aktivitas 1: Pembelahan Amoeba dan Fragmentasi Planaria sebagai Bentuk Penggandaan/Pengulangan

Tujuan dari aktivitas ini adalah melihat kemampuan siswa menggambar Amoeba dan Planaria yang terbentuk berdasarkan video mengenai proses pembelahan Amoeba dan fragmentasi Planaria.

Sebelum memulai aktivitas 1, siswa terlebih dahulu diajak menonton video proses pembelahan Amoeba dan fragmentasi Planaria untuk menstimulus pengetahuan awal mereka mengenai proses perkembangbiakan hewan secara vegetatif.

Setelah itu siswa dibentuk dalam kelompok dimana satu kelompok terdiri dari 5-6 siswa yang dipilih secara acak. Setiap kelompok diberikan LAS yang dapat memfasilitasi mereka dalam memperoleh pengetahuan sesuai dengan tujuan pembelajaran. 
Permasalahan yang diberikan adalah menentukan banyak Amoeba dan Planaria baru yang terbentuk pada setiap tahapnya berdasarkan gambar yang telah dibuat siswa pada masalah sebelumnya. Masalah ini digunakan untuk menunjukkan proses penggandaan atau pengulangan suatu bilangan yang terbentuk dari perkembangbiakan Amoeba dan Planaria.

Gambar 4 berikut merupakan jawaban siswa dalam menentukan banyak Amoeba/Planaria baru yang terbentuk.

Permasalahan:

Buatlah gambar proses pembelahan Amoeba dari Amoeba awal sampai pembelahan keempat! Hitunglah banyaknya Amoeba yang terbentuk pada masing-masing pembelahan! Jawaban:
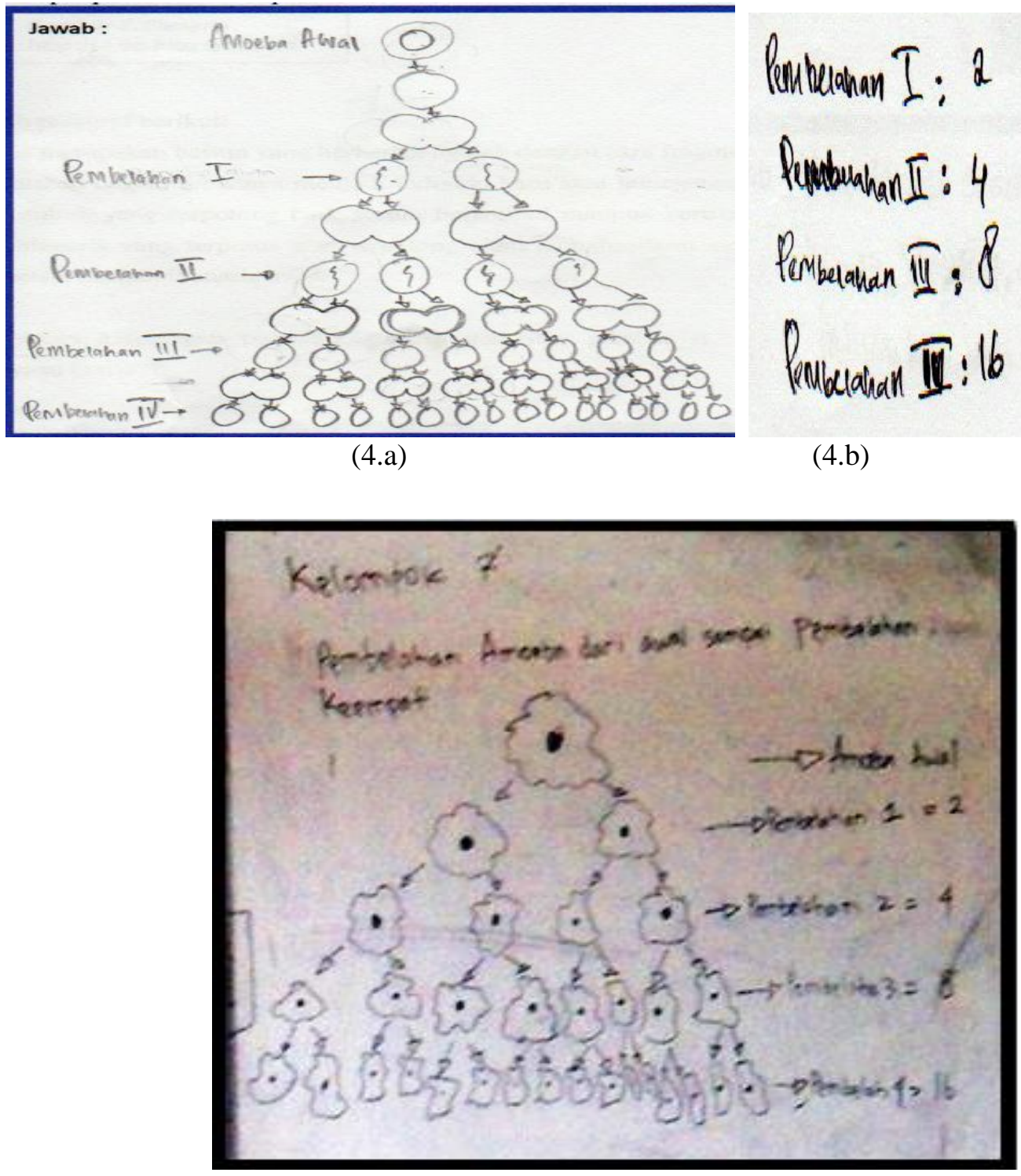

(4.c) 
Permasalahan:

Jika seekor Planaria dipotong menjadi 3 bagian dan setiap potongan akan berkembang menjadi Planaria baru, dapatkah kamu menggambarkan apa yang terjadi sampai potongan ketiga?

Jawaban:

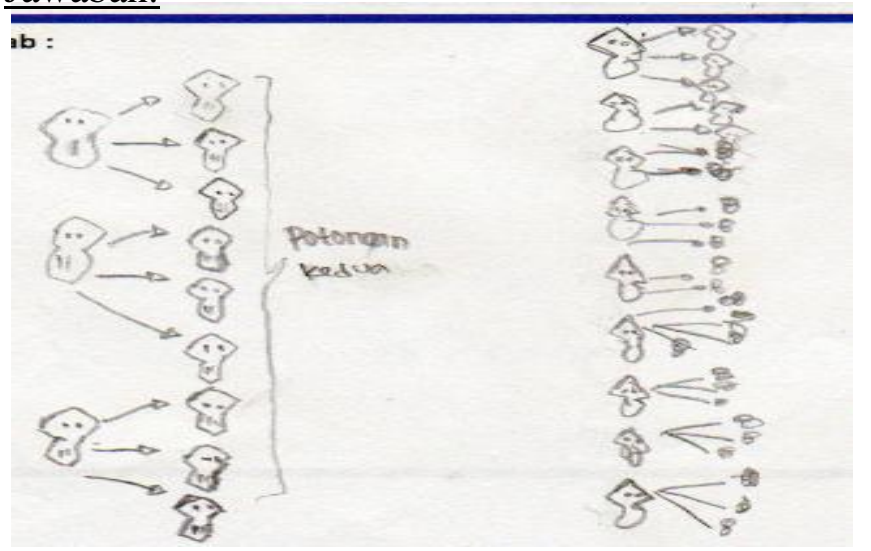

(4.d)

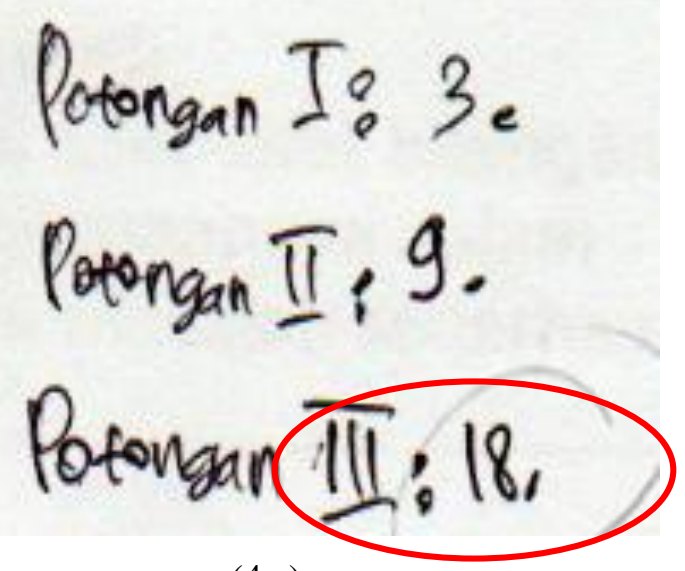

(4.e)

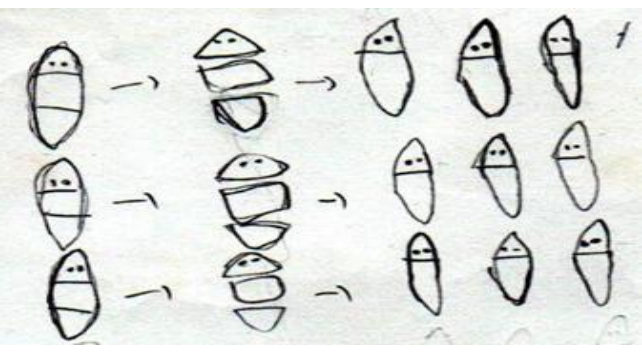

(4.f)

Gambar 4. Jawaban Siswa pada LAS 1

3. Aktivitas 2: Bentuk Perpangkatan

Tujuan aktivitas ini adalah siswa dapat menjelaskan pengetian bilangan berpangkat melalui pertanyaan-pertanyaan sebanyak 4 soal yang ada di LAS. Pertanyaan yang terdiri dari 4 soal tersebut dimaksudkan untuk membantu siswa menemukan sendiri pengertian bilangan berpangkat. Berikut ini merupakan jawaban siswa mengenai bentuk perkalian berulang, perpangkatan, dan definisi perpangkatan yang mereka dapatkan.

Permasalahan:

Tuliskan bentuk perkalian menggunakan bilangan yang sama untuk menjabarkan banyak Amoeba pada masing-masing pembelahan!

\section{Jawaban:}

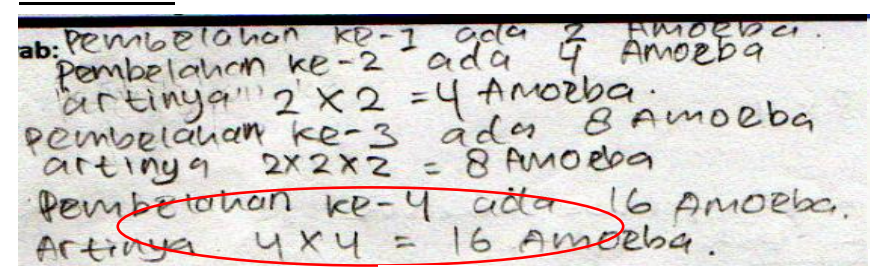

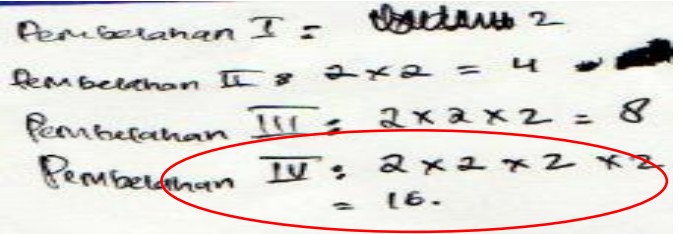

$5 . b$ 
Permasalahan:

Tuliskan pula bentuk perkalian menggunakan bilangan yang sama untuk menjabarkan banyak Planaria (bila dipotong menjadi 3) pada masing-masing potongan!

Jawaban:

$$
\begin{aligned}
& \text { Pemotomatan I: } 3 \\
& \text { Pemotongan I! }=3 \times 3=5 \\
& \text { Pemotongan tis: } 3 \times 3 \times 3=27
\end{aligned}
$$

5.c

Gambar 5. Strategi Siswa dalam Pengulangan

Permasalahan:

Berdasarkan jawaban yang Kamu peroleh di atas. Lengkapilah tabel di bawah ini!

Jawaban:

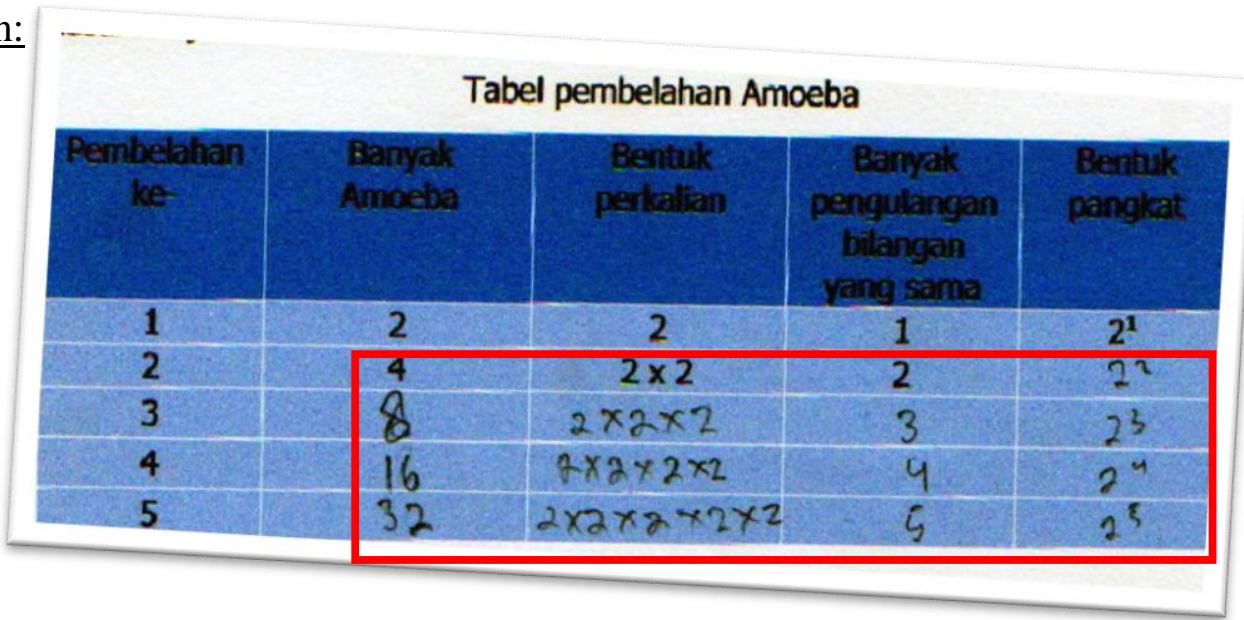

6.a

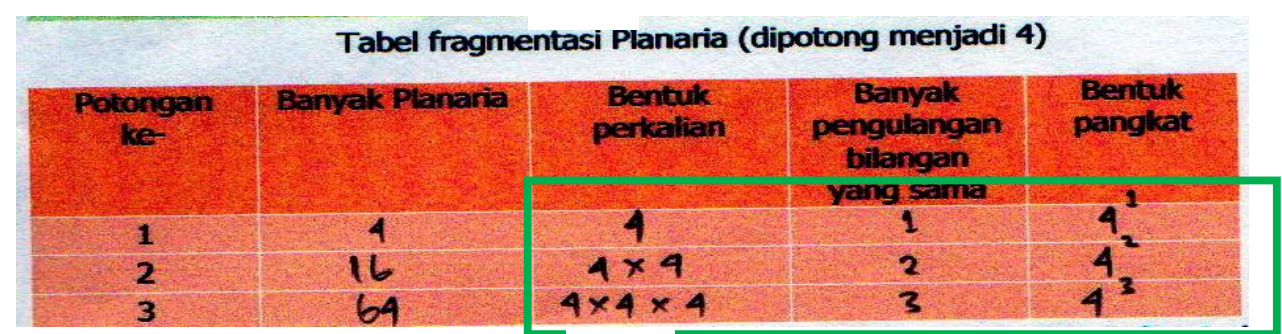

6.b

Tabel fragmentasi Planaria (dipotong menjadi 4)

\begin{tabular}{c|cccc|}
$\begin{array}{c}\text { Potongan } \\
\text { ke- }\end{array}$ & Banyak Planaria & $\begin{array}{c}\text { Bentuk } \\
\text { perkalian }\end{array}$ & $\begin{array}{c}\text { Banyak } \\
\text { pengulangan } \\
\text { bilangan } \\
\text { vana sama }\end{array}$ & $\begin{array}{c}\text { Bentuk } \\
\text { pangkat }\end{array}$ \\
\hline 1 & 4 & $2 \times 2$ & 2 & $2^{2}$ \\
2 & 16 & $4 \times 4$ & 2 & $4^{2}$ \\
3 & 64 & $8 \times 8$ & 2 & $8^{2}$ \\
\hline
\end{tabular}

6.c 
Permasalahan:

Berdasarkan apa yang telah kalian jawab di atas, lengkapilah kalimat berikut sesuai dengan pendapat Kalian!

Jawaban:

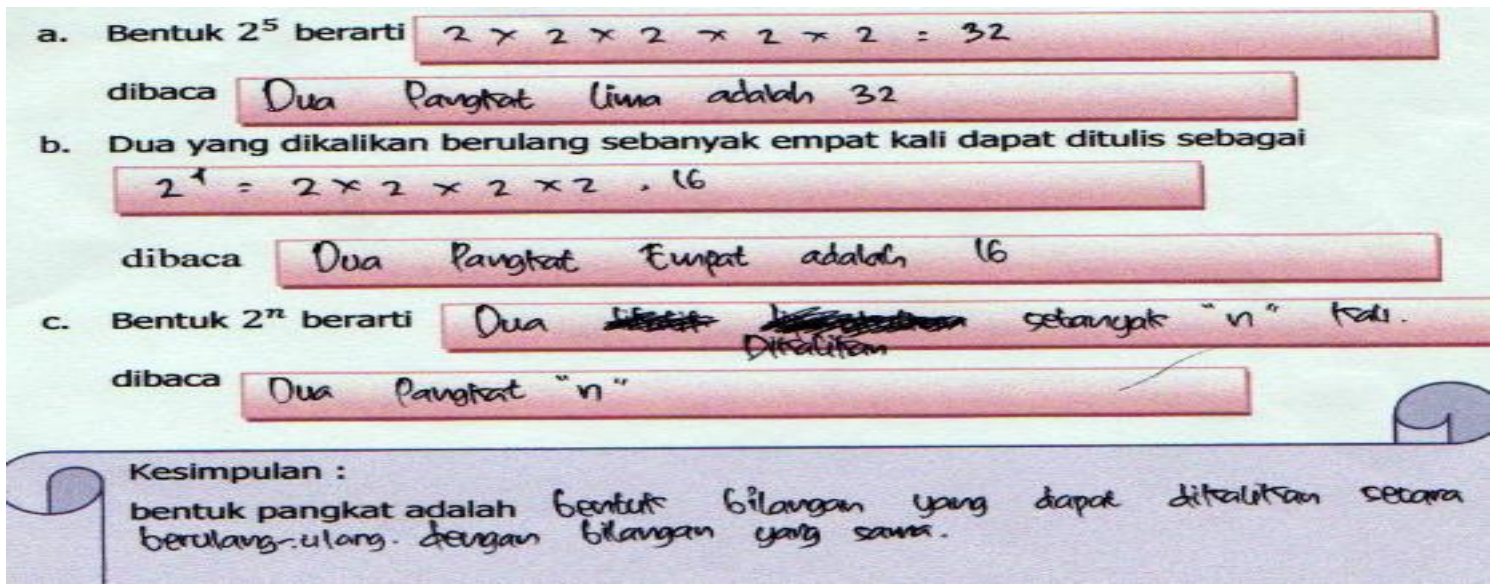

6.d

Gambar 6. Beberapa Jawaban Siswa Nomor 4 dan 5

\section{Aktivitas 3: Contextual Problem}

Pada aktivitas ini siswa diberikan permasalahan yang mempunyai hubungan dengan perpangkatan. Masalah yang diberikan disesuaikan dengan tujuan yang telah dicapai pada dua aktivitas sebelumnya. Permasalahan ini akan dikerjakan siswa secara berkelompok dengan tujuan siswa bisa saling bertukar pendapat dan saling memberikan bantuan dalam menyelesaikan permasalahan yang ada sehingga akan lebih mempersiapkan siswa jika diberikan soal-soal bentuk pangkat lainnya. Pada Gambar di bawah ini merupakan jawaban dan strategi siswa atas permasalahan yang diberikan.

\section{Permasalahan 1:}

a. Buatlah bentuk pangkat dari sebuah rak telur di bawah ini!

b. Jika Karina membeli 5 rak telur. Berapakah jumlah semua telur yang dibelinya? Tuliskan bentuk pangkatnya!

1. Perhatikan gambar di bawah ini!

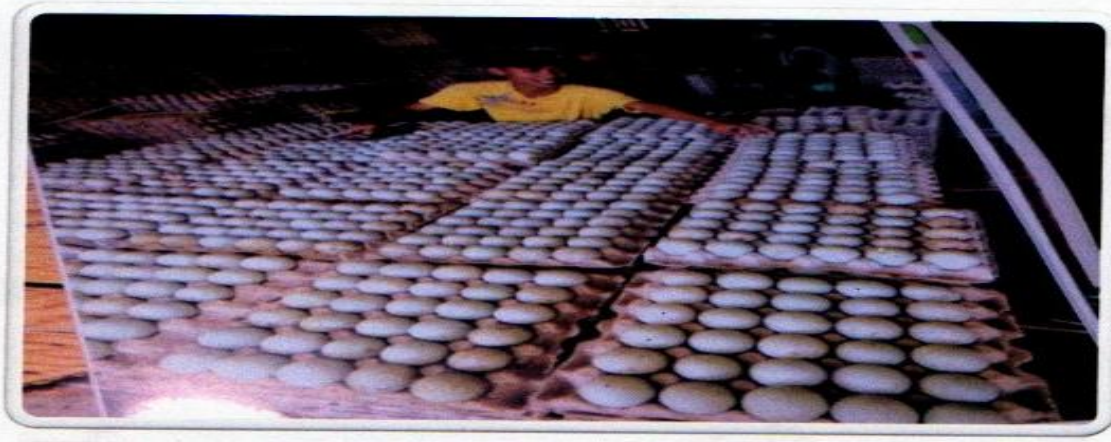


Jawaban :

Jawab: Hicak bisa dipangtatan karera taktorkasi dari 30 addah 2,3,5. Katena 2,3,5 bukan bilangan sama maka catu rak telur tersebot tidak dapat diparglat kan

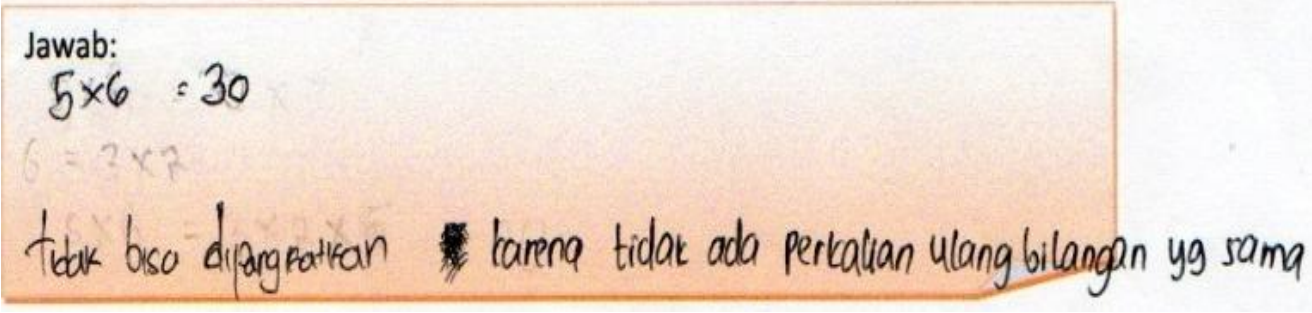

(7.b)

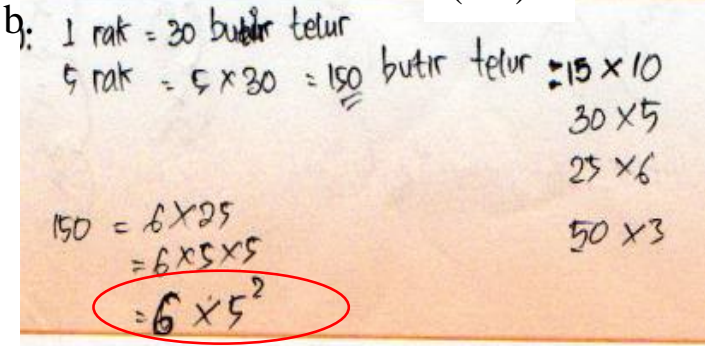

(7.c)

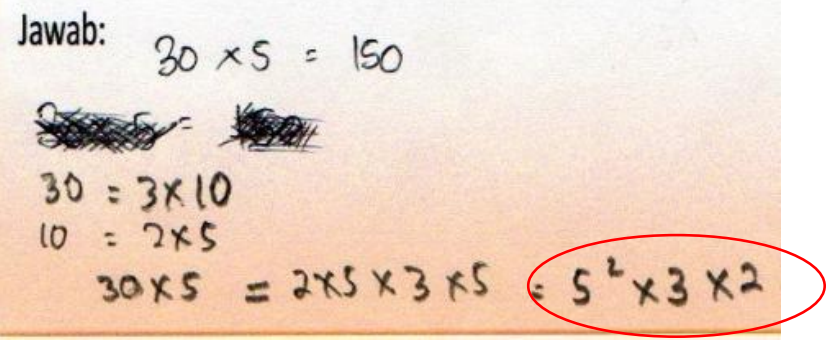

(7.d)

Gambar 7. Jawaban Beberapa Kelompok untuk Soal Nomor 1

Permasalahan:

Perhatikan gambar segitiga-segitiga di bawah ini!

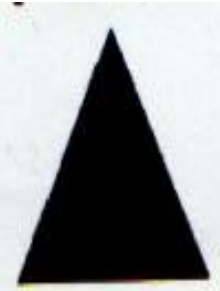

Tahap 1

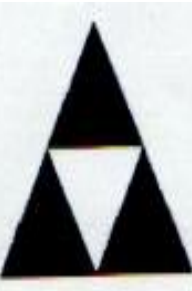

Tahap 2

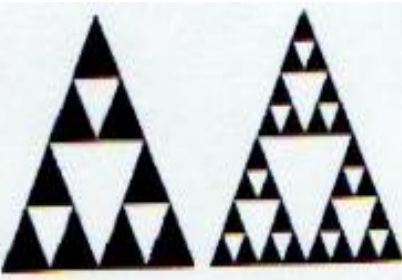

Tahap 3

Tahap 4

Tahap 5

Segitiga yang berwarna hitam disebut segitiga Sierpinski. Segitiga itu membagi dirinya menjadi bentuk yang sama dan ukuran yang terus berubah. Pada tahap 1 terdiri atas 1 segitiga Sierpinski, kemudian pada tahap 2 segitiga Sierpinski membagi dirinya menjadi 3 segitiga Sierpinski, dan begitu seterusnya.

Berapa banyak segitiga Sierpinski yang dihasilkan pada tahap ke 5? Jelaskan jawabanmu! 
Jawaban:

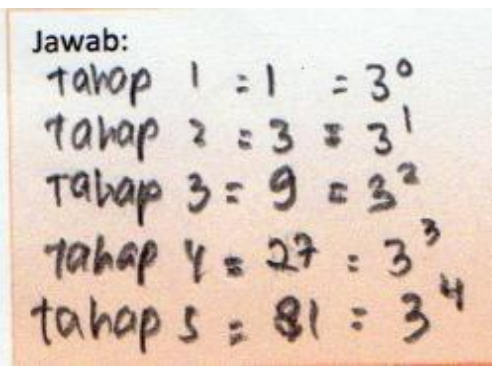

(8.a)

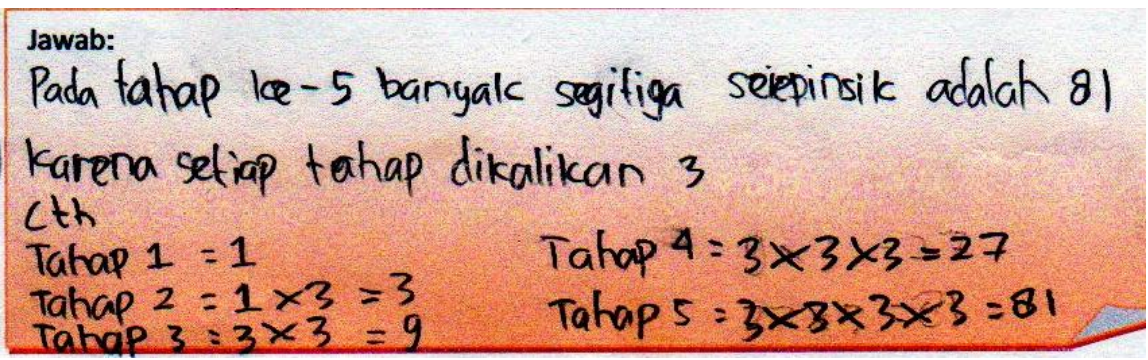

(8.b)

Gambar 8. Jawaban Kelompok Euglena dan Protozoa

Permasalahan:

Sebuah benda mempunyai massa $m \mathrm{~kg}$ dan bergerak dengan kecepatan $v \mathrm{~m} / \mathrm{dtk}$. Energi kinetik (Ek) benda tersebut dirumuskan dengan $E k=\frac{1}{2} m v^{2}$. Hitunglah berapa joule Energi kinetik jika benda itu memiliki massa $6 \mathrm{~kg}$ dan bergerak dengan kecepatan $27 \mathrm{~m} / \mathrm{dtk}$ ? (jawaban dalam bentuk pangkat)

Jawaban:

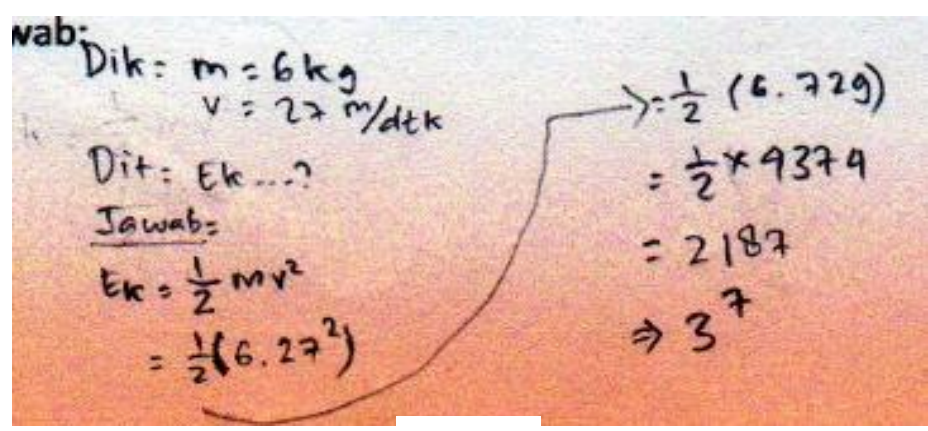

(9.a)

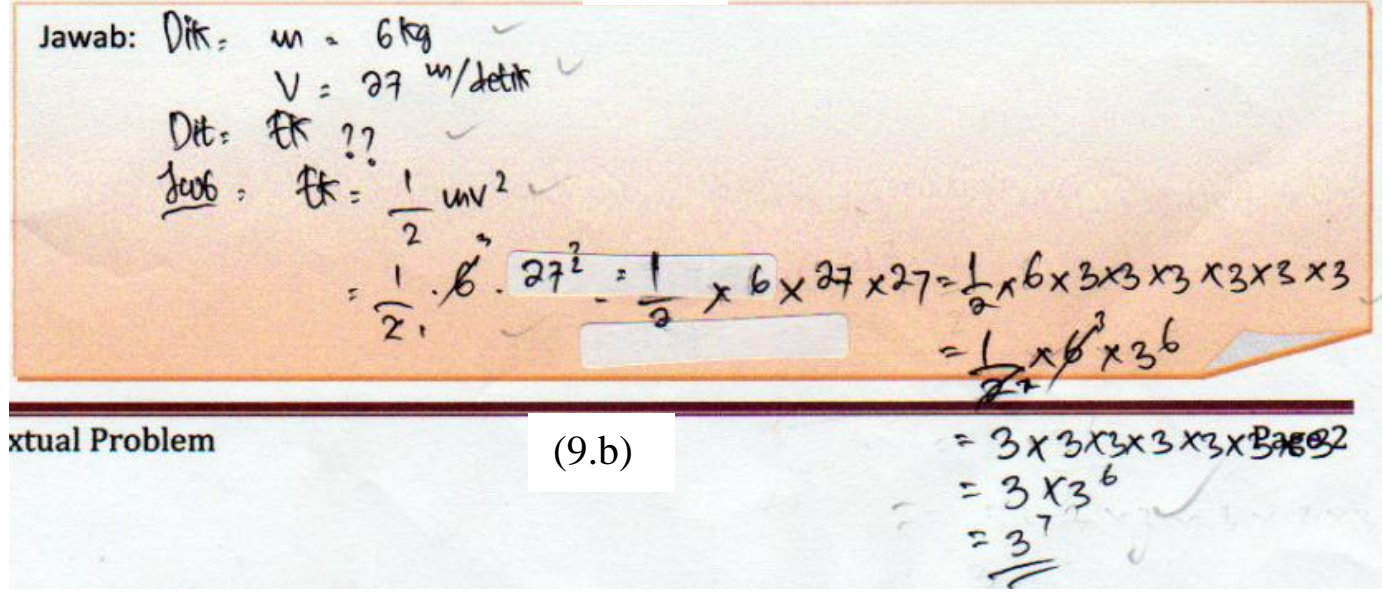

Gambar 9. Perbedaan Strategi pada Kelompok Hydra dan Paramaecium

\section{Tes Akhir}

Tes akhir diberikan kepada semua siswa dan dikerjakan secara individu. Tujuan diberikannya tes akhir ini adalah untuk mengukur pemahaman siswa setelah mengikuti 
seluruh aktivitas pembelajaran. Ada lima permasalahan yang diberikan pada tes akhir ini. Beberapa jawaban dan strategi siswa dalam menjawab tes akhir antara lain:

Permasalahan 1:

Diberikan susunan bilangan seperti berikut: 16, 25, 36, 49, a, b, c. Bilangan apa yang tepat untuk menggantikan a, b, dan c? Mengapa?

Jawaban:
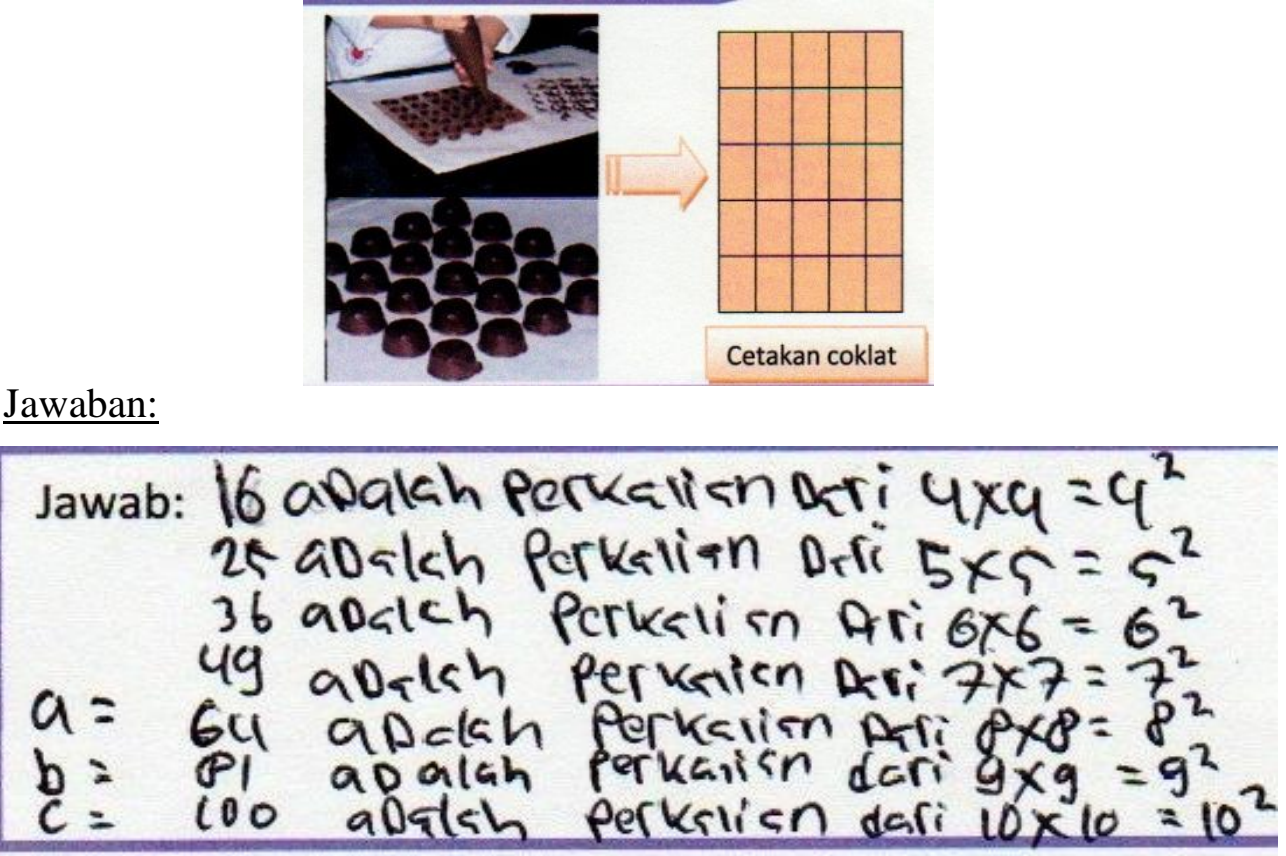

Gambar 10. Jawaban JHNS

Permasalahan 2:

Jawablah hasil yang diperoleh dari operasi berikut $20^{3} \times 4^{2} \div 10^{3}$ dalam bentuk pangkat!

Jawaban:

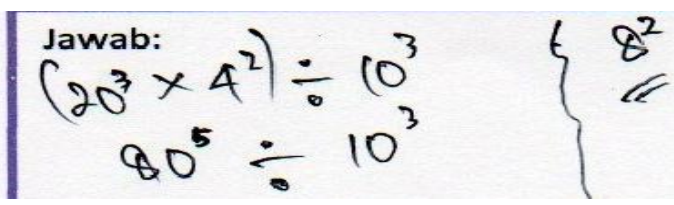

Gambar 11. Jawaban Keliru dari G

Permasalahan 3:

Catrin mempunyai hobi membuat coklat. Hari ini Dia akan membuat coklat untuk ulang tahun adiknya. Berapa banyak cetakan yang harus disiapkan Catrin supaya coklat yang dihasilkan sebanyak $5^{3}$ buah? Jelaskan jawabanmu!

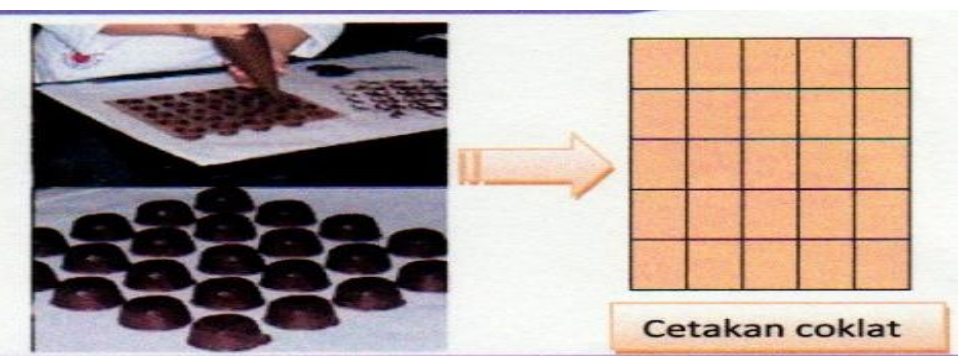


Jawaban:

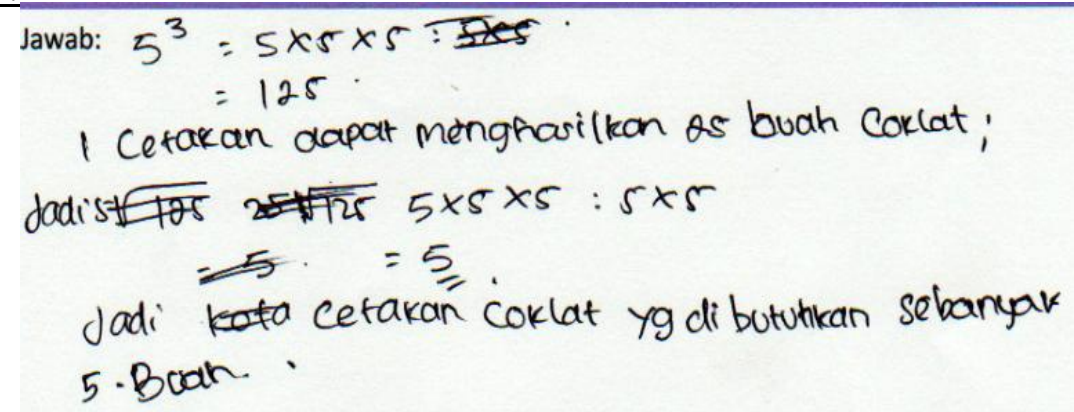

Gambar 12. Strategi Jawaban R

Permasalahan 4:

Sean dan Dean berselisih pendapat mengenai nilai $(6 p)^{2}$ dan $6 p^{2}$. Menurutmu, manakah yang lebih besar jika: a. $p=2 \quad$ b. $p=\frac{1}{2}$

Jelaskan jawabanmu!

Jawaban:

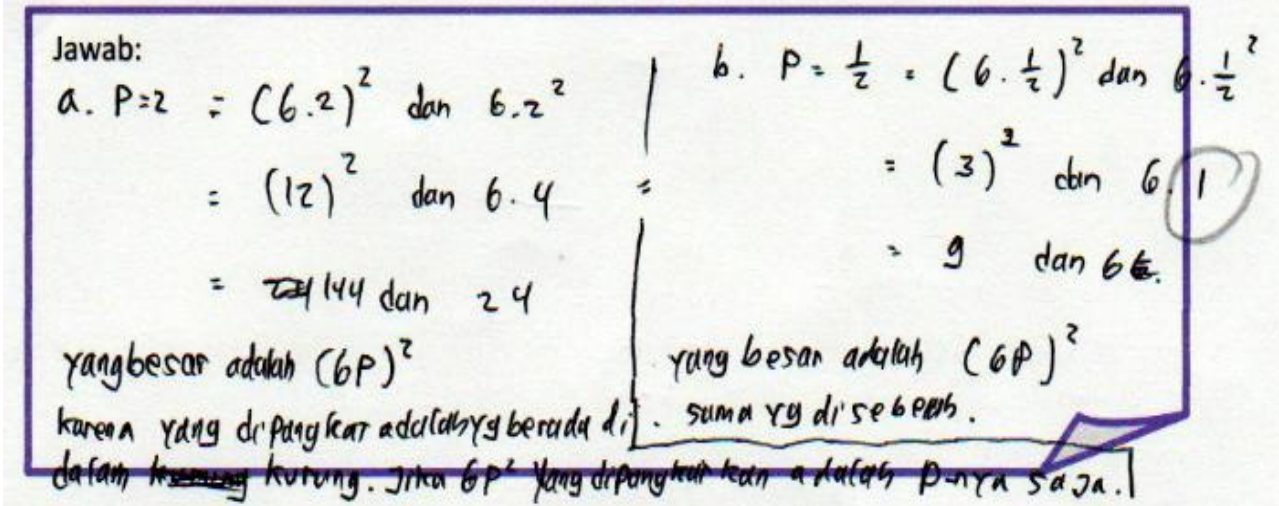

Gambar 13. Jawaban M.Z

Permasalahan 5:

Jumlah Amoeba mula-mula adalah 32 ekor. Setiap harinya Amoeba tersebut akan berkembangbiak dengan ketentuan $M_{n}=M_{o}\left(\frac{3}{2}\right)^{n}$. Berapakah jumlah Amoeba tersebut setelah hari ke-5?

(catatan: $M_{o}=$ Amoeba mula - mula, $n=$ hari)

Jawaban:

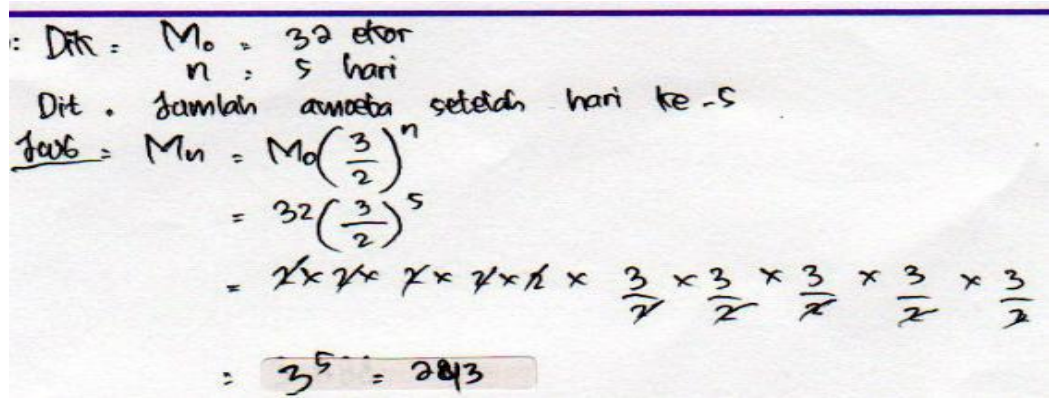

Gambar 14. Strategi Jawaban R.P 


\section{Pembahasan}

\section{Tes Awal}

Berdasarkan hasil yang diperoleh dari tes awal, dapat disimpulkan bahwa siswa sudah mampu menggambar sesuai aturan kue yang diberikan (lihat Gambar 1a), hanya saja ada siswa yang beralasan agar kue terlihat cantik maka susunannya dibuat seperti lingkaran (lihat Gambar 1b). Akan tetapi, siswa sudah memiliki strategi sendiri untuk menghitung banyak kue yang ada (lihat Gambar 1c dan 1d). Kemampuan ini merupakan prasyarat untuk aktivitas 1 nanti. Namun, ternyata siswa belum memahami konsep perpangkatan walaupun sebenarnya mereka telah mempelajari bilangan kuadrat dan pengkubikan. Hal tersebut dapat terlihat pada Gambar 2a dan 2b. Siswa belum bisa memberikan alasan mengapa sebuah bilangan tidak bisa dipangkatkan. Hal ini sesuai dengan hasil penelitian Mahmuda (2011), yakni kesalahan siswa dalam memahami konsep perpangkatan mengakibatkan kesalahan prosedural. Berdasarkan hasil tersebut pula peneliti dapat menyimpulkan bahwa pengetahuan perkalian siswa cukup untuk mengikuti beberapa aktivitas yang telah dirancang pada HLT.

\section{Aktivitas 1}

Secara umum, jawaban siswa mengenai permasalahan yang diberikan sudah sesuai dengan apa yang dirumuskan sebelumnya, yaitu siswa sudah mampu menentukan banyak Amoeba dan Planaria yang dihasilkan pada setiap tahapnya dengan cara menghitung berdasarkan gambar yang siswa buat. Hal tersebut terlihat pada Gambar 4a, 4c dan 4d. Pada gambar tersebut terlihat proses penggandaan hewan yang telah dipahami siswa melalui gambar yang siswa buat. Hanya saja pada gambar 4f, salah satu kelompok tidak memperhatikan aturan yang ada sehingga siswa menganggap ketika planaria dipotong menjadi tiga telah dihitung sebagai tahap kedua. Oleh karena itu, pada tahap ketiga hanya menghasilkan 9 planaria baru, yang seharusnya pada tahap ketiga ada 27 planaria. Kesalahan juga terjadi pada saat menghitung banyak Planaria baru (Gambar 4e), setelah diwawancara ternyata kelompok tersebut masih terpengaruh dari pembelahan Amoeba yang setiap tahapnya dikalikan 2 (lihat Gambar 4b). Hal ini tidak menjadi permasalahan karena siswa telah mengenali bentuk pengulangan yang terjadi. Dengan adanya kemampuan ini, maka siswa diharapkan mampu menyelesaikan aktivitas yang peneliti rancang selanjutnya. Menurut Ormrod (2008:139) bahwa saat akan memperkenalkan topik baru, kita harus mengaitkannya dengan pengetahuan yang telah dimiliki siswa sehingga menghasilkan pembelajaran yang bermakna, mengaitkan tugas-tugas dan aktivitas di kelas dengan 
kebutuhan dan minat harian siswa yang spesifik, meningkatkan nilai yang dilekatkan siswa tentang berbagai masalah dan pertanyaan yang mereka pelajari di kelas, dan membantu siswa untuk menguasai keterampilan dan strategi yang akan mereka butuhkan untuk mencapai tujuan pendidikan.

\section{Aktivitas 2}

Berdasarkan hasil jawaban siswa untuk aktivitas kedua ini, terlihat bahwa siswa mampu membentuk sebuah bilangan menjadi perkalian menggunakan bilangan yang sama (lihat Gambar 5a, 5b, dan 5c). Terlebih lagi ketika jawaban siswa menunjukkan perbedaan (lihat Gambar 6a, 6b, dan 6c). Hal tersebut bukanlah menjadi masalah tetapi justru menambah pengetahuan siswa mengenai bentuk perkalian bilangan yang sama. Perbedaan yang ada akan dipresentasikan, karena menurut Muzayyanah (2009) presentasi memberikan kesempatan kepada siswa untuk mengungkapkan pendapat siswa sehingga siswa merasa dihargai dan akhirnya akan merasa senang mengikuti pembelajaran. Hal itu pula yang akan dijadikan dasar untuk memahami syarat bentuk perpangkatan dimana bilangan yang dikalikan harus sama. Untuk kemudian siswa dapat menjelaskan definisi dari bentuk pangkat yang siswa temukan (lihat Gambar 6d).

\section{Aktivitas 3}

Berdasarkan hasil yang diperoleh pada aktivitas ini, kemampuan siswa dalam memahami konsep pangkat semakin baik. Hal tersebut terlihat pada Gambar 7, siswa sudah memahami hal terpenting dari bentuk pangkat yaitu perkalian beberapa bilangan bisa diubah menjadi bentuk pangkat apabila dalam perkalian tersebut terdapat bilangan yang sama.

Pada Gambar 8, terlihat bahwa siswa sudah mampu menemukan bentuk pengulangan yang ada pada "segitiga Sierpinski" tersebut bahkan siswa juga sudah menemukan bentuk pangkat yang sesuai dengan banyak segitiga Sierpinski yang terbentuk.

Konsep pangkat telah dipahami siswa dengan baik. Hal tersebut terlihat pada Gambar 9b bahwa salah satu kelompok menjawab permasalahan dengan menguraikan terlebih dahulu bilangan 27 menjadi perkalian berulang tiga untuk kemudian dikelompokkan sehingga menghasilkan bilangan berpangkat yang diinginkan. Hal tersebut tentu saja lebih mudah dilakukan karena tidak memerlukan perhitungan yang besar. Menurut Van de Walle (2008) bahwa ketika siswa menemukan kesulitan dalam mengerjakan soal sebaiknya siswa menggunakan bentuk yang ekuivalen tanpa pangkat. 
Dilihat dari segi konjektur yang didesain dalam penelitian ini untuk mengantisipasi strategi/pemikiran siswa, sebagian besar konjektur-konjektur yang disusun sesuai dengan strategi berpikir siswa. Dengan demikian penemuan dalam penelitian merupakan bagian yang tidak terpisahkan dari pengembangan LIT dalam hal ini pendekatan PMRI dalam pembelajaran bentuk pangkat.

\section{Tes Akhir}

Secara umum, hasil analisis terhadap jawaban siswa pada saat tes akhir ternyata menunjukkan kemajuan. Hal tersebut membuktikan bahwa siswa mampu menggunakan definisi bentuk pangkat untuk menyelesaikan permasalahan yang diberikan. Permasalahan pertama pada Gambar 10 menunjukkan bahwa siswa telah mengenali bentuk perpangkatan walaupun soal yang disajikan tidak hanya menggunakan satu bilangan pokok. Siswa juga berani menjelaskan alasan mereka dalam menjawab soal yang diberikan.

Pada Gambar 11 terlihat kekeliruan siswa dalam menjawab permasalahan nomor 2. Siswa yang melakukan kesalahan adalah siswa yang dianggap memiliki kemampuan tinggi. Kekeliruan yang terjadi adalah siswa tidak menguraikan terlebih dahulu bilangan berpangkat dan langsung mengooperasikannya menjadi perkalian lalu pembagian tanpa memperhatikan pula bilangan pokoknya. Hal tersebut sesuai dengan hasil penelitian Rudiati (2012) bahwa siswa hanya menghafal konsep/rumus saja dan kurang mampu menggunakan konsep tersebut jika menemui masalah dalam kehidupan nyata.

Pada gambar 12, 13 dan 14 terlihat beberapa strategi siswa untuk mewakili jawaban yang benar. Secara umum dapat disimpulkan bahwa siswa mampu menyelesaikan permasalahan yang diberikan karena siswa telah memiliki pengalaman saat menyelesaikan jenis-jenis masalah ketika mereka mengikuti pembelajaran. Menurut Duffin dan Simpson (dalam Kesumawati, 2005:230) bahwa pemahaman konsep sebagai kemampuan siswa untuk mengungkapkan kembali apa yang telah dikomunikasikan dengannya. Dengan kata lain, aktivitas yang telah dirancang dan diskusi kelas memiliki pengaruh yang baik, sehingga mampu membantu siswa memahami konsep bentuk pangkat.

\section{SIMPULAN}

Berdasarkan hasil penelitian, maka dapat disimpulkan bahwa lintasan belajar yang dihasilkan dapat membantu siswa memahami konsep bentuk pangkat melalui konteks perkembangbiakan hewan secara vegetatif.

Lintasan belajar yang telah dilalui siswa meliputi 3 aktivitas yaitu: 
1. Pembelahan Amoeba dan fragmentasi Planaria

Pemahaman siswa terhadap bentuk penggandaan terlihat dari gambar Amoeba dan Planaria yang sebagai model yang siswa buat sendiri. Berdasarkan hal tersebut pula, selanjutnya siswa mampu menghitung banyak Amoeba dan Planaria baru yang terbentuk setiap tahapannya yang menunjukkan adanya proses penggandaan yang terhadap Amoeba dan Planaria Awal.

\section{Mendefinisi Bentuk Pangkat}

Berdasarkan banyak Amoeba dan Planaria baru dalam setiap tahapnya, siswa mampu menemukan bentuk perkalian berulang untuk kemudian ditulis ke dalam bentuk perpangkatan berdasarkan. Hal tersebut, dapat membantu siswa menjelaskan pengertian bentuk pangkat menggunakan kalimatnya sendiri dan sesuai dengan konsep bentuk pangkat itu sendiri.

3. Menyelesaikan Permasalahan Bentuk Pangkat

Melalui pemahaman siswa tentang konsep bentuk pangkat, dapat membantu siswa dalam menyelesaikan persoalan yang berhubungan dengan bentuk pangkat. Baik mengubah perkalian menjadi bentuk pangkat maupun menguraikan bentuk pangkat suatu bilangan menjadi bentuk perkalian berulangnya dengan benar. Strategi yang dilakukan adalah ketika siswa menemukan kesulitan, siswa menjabarkan bentuk perpangkatan itu menjadi perkalian berulang barulah siswa melakukan prosedur selanjutnya.

\section{DAFTAR PUSTAKA}

Agustin, K., \& Linguistika, Y. (2012). Identifikasi Kesalahan Siswa Kelas X pada Evaluasi Materi Sifat-sifat Bilangan Berpangkat dengan Pangkat Bilangan Bulat di SMA Muhammadiyah 2 Yogyakarta. Seminar Nasional Matematika dan Pendidikan Matematika di Jurusan Pendidikan Matematika FMIPA UNY. (online). eprints.uny.ac.id/8097/1/P - 50.pdf. diakses 20 Oktober 2012.

de Lange, J. (1987). Mathematics, Insight and Meaning. Utrecht: OW \& OC, The Netherlands.

Freudenthal, H. (1991). Revisiting Mathematics Education. Dordrecht: Kluwer Academic Publisher.

Gravemeijer, K. P. E., \& Cobb, P. (2006). Design Research From A Learning Design Perspective. In J. V. D Akker, K. P. E Gravemeijer, S. McKenney, N. Nieven (Eds.), Educational Design Research (pp. 17-51). London: Routledge.

Kanginan, Marthen. (2004). Matematika. Bandung: Grafindo Media Utama.

Kesumawati, Nila. (2005). Pemahaman konsep matematika dalam pembelajaran matematika. (Online). Tersedia: http://P-8\%20Pendidikan\%28Nila\%20K\%29.pdf. Diakses 1 Juli 2013.

Kuswanti. (2008). Contextual Teaching and Learning Ilmu Pengetahuan Alam: Sekolah Menengah Pertama / Madrasah Tsanawiyah Kelas IX. Jakarta: Pusat Perbukuan, Departemen Pendidikan Nasional. 
Mahmuda, A. (2012). Diagnosis Kesalahan Siswa Menyelesaikan Soal Bentuk Pangkat. Skripsi: Fakultas MIPA UM. (online). http://karyailmiah.um.ac.id/index.php/matematika/article/view/16041. Diakses 20 Oktober 2012.

Muzayyanah, A. (2009). Peningkatan kemampuan komunikasi matematika siswa dalam pembelajaran matematika melalui model pembelajaran kooperatif tipe think-pair-share (TPS) di SMA Negeri 1 Godean. Dalam Prosiding Seminar Nasional Pembelajaran Matematika Sekolah, 6 Desember 2009, Jurusan Pendidikan Matematika FMIPA UNY, 300-318. Universitas Negeri Yogyakarta.

Ormrod, J. E. (2008). Psikologi pendidikan: Membantu siswa tumbuh dan berkembang. Jilid kedua. Diterjemahkan oleh Amitya Kumara. Jakarta: Erlangga.

Plomp, T., \& Nieveen, N. (2007). Educational Design Research: an Introduction. In Plomp, T., \& Nieveen, N. (Editor). An Introduction to Educational Design Research (pp. 9-35). Enschede: slo.

Rudiati, N. (2012). Implementasi Pembelajaran Berbasis Masalah (Problem Based Learning) dengan Teknik Resitasi dalam Kurikulum Tingkat Satuan Pendidikan (KTSP) untuk Meningkatkan Kualitas Proses dan hasil Belajar pada Materi Bentuk Pangkat dan Bentuk Akar Siswa kelas X SMA N 1 Gondang Nganjuk tahun Ajaran 20111/2012. Seminar Nasional di Universitas PGRI Adhi Buana Surabaya. (online). http://digilib.unipasby.ac.id/files/disk1/2/gdlhub--niningrudi-92-1-niningr-i.pdf. Diakses 20 Oktober 2012.

Van de Walle, John A. (2008). Matematika Sekolah Dasar dan Menengah Jilid 2. Jakarta: Erlangga.

Wijaya, A. (2012). Pendidikan Matematika Realistik Suatu Alternatif Pendekatan Pembelajaran Matematika. Yogyakarta: Graha Ilmu. 